\title{
Review of pastoral practices in High Asia, edited by Hermann Kreutzmann. (Springer Series: Advances in Asian Human-Environmental Research)
}

\author{
Sarah Robinson
}

\author{
Correspondence: \\ sarah.robinson09@googlemail.com \\ Imperial College Conservation \\ Science Group, Division of Biology, \\ Imperial College London, Silwood \\ Park Campus, Ascot SL5 7PY, UK
}

\author{
Book details \\ Kreutzmann, $\mathrm{H}$ (editor) \\ Pastoral Practices in High Asia \\ Dordrecht Heidelberg New York London, Springer; 2012. \\ 350 pages, ISBN 978-94-007-3845-4, ISBN 978-94-007-3846-1
}

Keywords: Pastoral systems, Mountains, Asia, Development

\section{Review}

The volume focusses on pastoral systems from the perspective of the social sciences and anthropology, with most chapters taking a case study approach. The studies cover the mountainous regions of Asia including the Himalaya, Karakorum, Pamir and Tien Shan ranges as well as six chapters focussing on the Tibetan plateau. The authors include Indian, Chinese, European and American academics - many of whom have spent many months or years living in their study areas.

A key question posed by the editor in the introductory chapter is whether pastoralism is a flexible strategy to adapt to changing conditions or an archaic and transitory stage on the path to modernity. The editor presents a conceptual framework which helps to tie the subsequent case studies together - pastoral systems are classed in terms of the extent to which they co-exist with agriculture, type of livestock mobility, location of home settlement in relation to other parts of the system, and presence of resettlement or sedentarization schemes.

The style and content of the subsequent chapters differ depending on the region with which they deal. The chapter on Pakistan focusses on the diversity of pastoral systems and on interactions and competition for pasture and forest resources between ethnic groups, some agro-pastoral, others nomadic. The Indian chapters describe migratory patterns and economic relationships between pastoralists and farmers, the state and other stakeholders in Kinnaur and the Kumaon Himalaya. Change is certainly present - co-existence and practices are threatened by population growth and migration, but these forces are gradual. The other chapters of the book concern systems in which change has occurred on a grand scale over the past 20 years.

(C) 2013 Robinson; licensee Springer. This is an Open Access article distributed under the terms of the Creative Commons Attribution License (http://creativecommons.org/licenses/by/2.0), which permits unrestricted use, distribution, and reproduction in any medium, provided the original work is properly cited. 
In Afghanistan, Chapter 3 describes how co-existence between the highly nomadic Kuchi and local pasture users in the key summer pastures of Badakhshan has broken down as rules of access have been determined by armed strongmen and militias. Extreme tenure insecurity now characterises the system in the absence of a rule of law. Conversely, the Afghan Kyrgyz are surely one of the most isolated pastoral populations in the world - the story of the exodus of part of the population to Turkey during the Soviet-Afghan war and the survival of the remainder in the remote Wakhan corridor is extraordinary. The author of Chapter 4 presents here some of the first material on this population published since the 1970s. He focusses on their response to the re-opening of their world since the 1990s.

Four additional chapters also focus on Kyrgyz populations - in Kyrgyzstan, Tajikistan (Eastern Pamir) and Xinjiang. These groups were all formerly part of collectivised state-run systems which have been either slowly dismantled in recent years (in China) or fell apart abruptly in 1991.

The chapter on Tajikistan and two chapters on Kyrgyzstan illustrate the extreme hardships experienced in rural areas following the collapse of the Soviet Union. Common to these studies is the initial collapse in livestock inventories - only a very small number of people had both the vision and opportunity to accumulate livestock at this time, and this early socio-economic stratification is now a defining feature of pastoral areas in these countries. Chapter 8 focusses on the role of uncertainty in the new post-Soviet world and its effects on decision-making, whilst Chapter 7 discusses pastoral tenure and conflicts over user rights between different types of stakeholders. All three studies indicate that the steep decline in livestock numbers has been followed by recovery and increasing competition for pastures. A lack of employment alternatives means that pastoralism's importance as a livelihood strategy (usually combined with agriculture) has grown - but such livelihoods are precarious and poverty is widespread. The state is virtually absent.

The contrast with China could not be more stark - the chapter on Xinjiang and five of the six covering the Tibetan plateau (including the Tibet Autonomous Region, Qinghai province and parts of Gansu, Sichuan and Yunnan provinces) illustrate how the Chinese state is determined to either bring services to pastoralists or vice versa, and describe recent attempts to intensify livestock production. The scientific arguments on whether such intensification is possible or sustainable are not really the focus of the book, but are mentioned, and much attention is given to impacts on pastoral practices such as livestock mobility, which are intimately bound up with sustainable use of the ecosystem. The chapters focus on the two major manifestations of Chinese modernisation policies in pastoral areas: resettlement and pasture enclosure programmes. Chapter 16 provides the most useful overview as it is not based on a single case study. Here, state policy is described in detail, and both costs and benefits of the policies are discussed in relation to the eastern part of the Tibetan plateau. This nuanced paper explains that there are very different types of resettlement programme; it includes a useful discussion on both the economic viability and ecological feasibility of the pasture enclosure programme and a section on local peoples' perceptions both for and against.

Chapters 12 to 15 comprise case studies and focus on the impact of the two policies on Tibetan society at specific localities. Topics include the effects of resettlement into housing estates, the role of new houses in Tibetan culture and the persistence of 
pastures as common property despite official privatisation programmes. The chapters do not tell one story - for example, it is not clear whether the fencing policy was designed to consolidate the division of rangeland into privately owned pieces of land or just to enclose reserve pasture for fodder harvesting, and both impressions are given in these case studies. The reader is left with the (probably correct) impression that the fencing and privatisation policies must be regionally very variable and their implementation even more so. All the studies emphasise a lack of consultation and information provision to pastoralists, and discrepancies between policy and its implementation. Improved community participation and programme evaluation is recommended by the authors.

The book ends with a discussion of the central questions of land rights and pressure on common pastures and on the role of the state and of the pastoralist communities themselves in determining their own futures. It is a useful and timely overview of pastoral systems in the region today.

Competing interests

The author declares that she has no competing interests.

Received: 30 November 2012 Accepted: 3 December 2012

Published: 9 January 2013

doi:10.1186/2041-7136-3-3

Cite this article as: Robinson: Review of pastoral practices in High Asia, edited by Hermann Kreutzmann. (Springer Series: Advances in Asian Human-Environmental Research). Pastoralism: Research, Policy and Practice 2013 3:3.

Submit your manuscript to a SpringerOpen ${ }^{\circ}$ journal and benefit from:

- Convenient online submission

- Rigorous peer review

- Immediate publication on acceptance

- Open access: articles freely available online

- High visibility within the field

- Retaining the copyright to your article

Submit your next manuscript at $>$ springeropen.com 